\title{
Role of macrophage secretions on rat polycystic ovary: its effect on apoptosis
}

\author{
Florencia Figueroa ${ }^{1}$, Alicia Motta ${ }^{3}$, Mariano Acosta ${ }^{2}$, Fabian Mohamed ${ }^{2}$, Liliana Oliveros ${ }^{1}$ \\ and Myriam Forneris ${ }^{1}$ \\ ${ }^{1}$ Laboratorio de Biología de la Reproducción, y ${ }^{2}$ Área Morfología, Departamento de Bioquímica y Ciencias \\ Biológicas, Facultad de Química, Bioquímica y Farmacia, Universidad Nacional de San Luis, Argentina, and \\ ${ }^{3}$ Laboratorio de Fisio-patología Ovárica (CEFYBO), Universidad de Buenos Aires, Argentina
}

Correspondence should be addressed to M Forneris; Email: mlforneris@gmail.com

\begin{abstract}
Polycystic ovarian syndrome is the most common endocrine disorder among women of reproductive age. Little is known about its etiology, although the evidence suggests an intrinsic ovarian abnormality in which endocrine, metabolic, neural and immune factors would be involved. In this work, the effects of macrophage (MO) secretion on ovarian apoptosis in a polycystic ovary syndrome rat model (PCO rat) induced by estradiol valerate are studied. Spleen MO secretions were used to stimulate ovaries and ovarian interstitial and granulosa cells from both PCO and control rats. Ovarian hormones and prostaglandin $E_{2}\left(P_{2} E_{2}\right)$ were measured by RIA; ovarian mRNA levels of Bax, Bcl2 and NFkB by RT-PCR; and ovarian inducible nitric oxide synthase (iNOS) by western blot. The number of apoptotic cells was evaluated by TUNEL. In the PCO ovary, the MO secretions from PCO rats increased the Bax and NFkB mRNA expressions and increased TUNEL staining in both granulosa and theca cells. In addition, the PCO MO secretions produced a decrease of nitric oxide release, iNOS protein level and $\mathrm{PGE}_{2}$ content in the $\mathrm{PCO}$ ovary, and it also induced an increase of androstenedione production by PCO interstitial cells, in comparison with control MO secretions. Considering these results and knowing that testosterone stimulates tumour necrosis factor- $\alpha$ production by PCO MO modifying ovarian response by increasing androstenedione, it is reasonable to suggest that the increase of androgens stimulated in ovarian cells by PCO MO secretions could in turn stimulate the cytokine production from MO, thus maintaining an apoptotic vicious cycle in the PCO ovary.

Reproduction (2015) 150 437-448
\end{abstract}

\section{Introduction}

The bidirectional communication between the neuroendocrine and immune system is firmly recognized. A number of hormonal and neuropeptide mediators have been shown to influence immune development and function in both healthy and diseased individuals (Bilbo \& Klein, 2012). The interactions between ovary and immune cells and the products such as steroids, peptide hormones, prostaglandins, growth factors and cytokines play a pivotal role in the regulation of ovarian function (Besedovsky \& del Rey 1996, Taub 2008).

The macrophages (MOs), the most abundant immune cells within the ovary, have been localized in thecal, luteal and interstitial tissue compartments and in the atretic follicle, in both animal and human. Their distribution fluctuates throughout the ovarian cycle with the highest numbers being present at proestrus and diestrus, strongly indicating hormonal regulation (Wu et al. 2004, 2007, Turner et al. 2011). MOs express functional sex hormone receptors and secrete nitric oxide (NO), along with tumour necrosis factor alpha
(TNF $\alpha$ ), prostaglandin $\mathrm{E}_{2}\left(\mathrm{PGE}_{2}\right)$, interleukin (IL)-1, IL6, IL10, IL12 and many other cytokines and growth factors that regulate ovarian function (Gallinelli et al. 2003, Sirotkin 2011). There is evidence that NO decreases ovarian steroidogenesis by inhibiting the steroid acute regulatory protein, $3 \beta$-hydroxysteroid dehydrogenase $(3 \beta-H S D)$ and cytochrome p450 side chain cleavage gene expression (Rekawiecki et al. 2005). Furthermore, $\mathrm{TNF} \alpha$ is a multifunctional cytokine that influences the reproductive axis, inducing changes that closely resemble those found in patients with hyperandrogenism (Thathapudi et al. 2014). TNF $\alpha$ plays a key role in follicular development and atresia, decreases ovarian cell viability and proliferation and stimulates apoptosis in cultured ovarian follicles (Greenfeld et al. 2007). When TNF $\alpha$ binds to its receptor (TNFR1), caspase- 8 and caspase- 3 are cleaved and activated, and the induction of $\mathrm{IkB}$ phosphorylation and degradation activate the nuclear factor kB (NFkB). Subsequently, NFkB translocates into the nucleus where it can activate the transcription of certain genes, particularly those involved 
in immune and inflammatory responses (Xiao et al. 2002). In addition, $\mathrm{PGE}_{2}$ modulates a variety of physiological processes including the production of inflammatory cytokines (Kuroda \& Yamashita 2003). $\mathrm{PGE}_{2}$ and its receptor subtypes, EP2 and EP4, are involved in the rat ovarian follicle growth (El-Nefiawy et al. 2005).

It is known that a fine balance between pro- and antiapoptotic factors may determine whether a follicle will continue developing or undergo atresia. Regulation of apoptotic signalling in the ovary is achieved by the Fas system and Bcl2 family, including Bcl2 (anti-apoptotic) and Bax (pro-apoptotic) proteins. The increased expression of the Bax death susceptibility gene coincides with the induction of apoptosis in granulosa cells during atresia in vivo and in vitro (Tilly 2001). Several studies suggest a cross-talk between the Fas/FasL systeminduced apoptosis and the nitric oxide-mediated anti-apoptotic pathway in ovarian follicle atresia (Chen et al. 2005, Krysko et al. 2008). Also, it has been shown that androgen and androgen receptors promote Bax-mediated apoptosis in prostate cancer cells (Lin et al. 2006). Furthermore, it is known that $\mathrm{PGE}_{2}$ promotesthe proliferation and survival of cells through apoptosis inhibition (Sheng et al. 1998, Rask et al. 2006).

Polycystic ovary syndrome (PCOS) is a common endocrine and metabolic disorder in women of reproductive age, characterized by anovulation, hyperandrogenemia and/or hyperandrogenism and, frequently, insulin resistance and hyperinsulinemia (Goodarzi et al. 2011). Ovaries from most women affected by PCOS are characterized by thecal/interstitial hyperplasia and increased expression of steroidogenic genes leading to greater androgen biosynthesis and cytochrome P450c17 $\propto$ gene expression (Nelson-Degrave et al. 2005).

Several studies suggest that the immune regulation may be involved in the etiology of PCOS (Amato et al. 2003, Niccoli et al. 2011). Furthermore, neuroimmunomodulatory factors such as dopamine have been associated to this disorder etiology (Gómez et al. 2011). We have shown a functional relationship between the ovarian androgens and immune cells in a rat model of PCOS induced by estradiol valerate (EV). The differential steroidogenic ability of $\mathrm{MO}$ secretions from those rats is associated to the in vitro testosterone environment. Testosterone, probably acting on $\mathrm{MO}$ androgen receptors, induces a greater release of TNF $\alpha$, modifying ovarian response by increasing androstenedione and slightly decreasing estradiol without affecting progesterone (Figueroa et al. 2012).

There is evidence that the dysfunction of granulosa cells may contribute to abnormal folliculogenesis, although the underlying mechanism remains to be determined. It has been demonstrated that there are significant differences in the rate of cell death and proliferation in granulosa cells in PCOS patients compared to women with regular ovulatory cycles. This was associated with decreased expression of apoptotic effectors and increased expression of a cell survival factor (Das et al. 2008). However, the role of immune cells on the apoptosis of the polycystic ovary remains obscure.

It is known that the EV-polycystic ovary syndrome rat model (PCO) is characterized by acyclicity, anovulation, hyperandrogenemia and polycystic ovarian morphology and associated with increased sympathetic activity resembling PCO (Brawer et al. 1986, Lara et al. 1993, Forneris et al. 2003), without metabolic disturbances such as dyslipidemia, insulin resistance or obesity (Stener-Victorin et al. 2005). Therefore, the aim of this study is to investigate in a rat model of PCOS induced by EV (PCO rats) whether secretions of MOs induce apoptosis in the ovary and if $\mathrm{MO}$ secretions modify the ovarian $\mathrm{PGE}_{2}$ and nitric oxide levels, and consequently the androstenedione response, to establish their relationship with the ovarian apoptosis. For that, secretions of MOs from the spleen were used to stimulate isolated ovarian cells and ovaries from PCO rats.

\section{Materials and methods}

\section{Reagents}

EV, fetal bovine serum and RPMI 1640 medium were purchased from Sigma. TRIzol reagent was obtained from Invitrogen/Life Technology. 1,2,6,7-[3 H]-Prostaglandin $\mathrm{E}$ $(107.0 \mathrm{Ci} / \mathrm{mmol})$ was provided by New England Nuclear Products (Boston, MA, USA). Other reagents and chemicals were of analytical grade.

\section{Animals and treatment}

Adult Holtzman cycling rats showing at least two regular 4-day cycles were used. They were housed in a controlled environment $\left(22-24{ }^{\circ} \mathrm{C}, 12 \mathrm{~h}\right.$ light: $12 \mathrm{~h}$ darkness cycle). They were allowed to eat and drink ad libitum. Animals were handled according to the procedures approved in the UFAW Handbook for the Care and Management of Laboratory Animals: Vol 1. Terrestrial vertebrates, 7th ed. (T Poole ed. (1999)), and the experimental protocol was approved by the Committee for the Use and Care of Animals of the National University of San Luis.

Two groups of rats were used. The first group consisted of PCO rats to which the PCOS model was induced at 60 days of age. This was accomplished by the administration of EV as a single i.m. injection ( $2 \mathrm{mg} / \mathrm{rat}$ diluted in $0.2 \mathrm{ml}$ corn oil) to resemble, in some aspects, the human syndrome (Brawer 1986). The second group, non-PCO rats (control rats), was injected with vehicle alone. All experiments were performed 2 months after EV injection, at which point cystic follicles were observed by light microscopy. Cystic follicles were devoid of oocytes and exhibited a large antral cavity, an enlarged thecal cell layer and a thin granulose-cell compartment. Because PCO rats predominantly showed cornified vaginal smears, control 
rats were sacrificed by decapitation on estrus day. The spleen and the ovaries were removed to obtain MOs for culture and ovarian incubations, respectively.

\section{MO culture}

The culture of $\mathrm{MO}$ was performed as described previously (Figueroa et al. 2012). Briefly, the spleens from PCO and control rats were washed in saline solution and pressed through a sterile nylon screen $(200 \mu \mathrm{m}$ mesh) to obtain the total cell populations. After centrifugation, the cells were resuspended in serum-free RPMI 1640 medium and treated with $\mathrm{NH}_{4} \mathrm{Cl}$. Cell number and viability were assessed microscopically using trypan blue exclusion, and $3 \times 10^{6}$ viable cells $/ \mathrm{ml}$ of medium were incubated in culture medium supplemented with $10 \%$ ( $v / v)$ heat-inactivated fetal bovine serum (FBS) and antibiotics (50 $\mu \mathrm{g} / \mathrm{ml}$ streptomycin and 50 units/ml penicillin), defined as basal medium, in culture plates. After incubation for $2 \mathrm{~h}$ at $37{ }^{\circ} \mathrm{C}$ in $95 \%$ air $/ 5 \% \mathrm{CO}_{2}$, the non-adhered cells were removed. The adhered MO monolayer showed $90 \%$ purity according to the morphologic analysis performed by Giemsa staining (Supplementary Figure 1, see section on supplementary data given at the end of this article) and nonspecific esterase staining. The MO from PCO rats (PCO MO), as well as the MO from control rats (control MO), were plated at a density of $1 \times 10^{6}$ cells/well in a final volume of $1 \mathrm{ml}$ in culture plates, preincubated in basal medium for $24 \mathrm{~h}$ and subsequently cultured for $24 \mathrm{~h}$. The respective culture media were collected and used to stimulate ovaries and isolated ovarian cells from PCO rats (PCO ovaries), as well as from control rats (control ovaries).

\section{Ovary incubation}

After sacrificing the rats, the PCO and control ovaries were halved and preincubated in $1 \mathrm{ml}$ of basal medium at $37^{\circ} \mathrm{C}$, in a $95 \% \mathrm{O}_{2} / 5 \% \mathrm{CO}_{2}$ mixture. After $15 \mathrm{~min}$, the incubation media were discarded and either $1 \mathrm{ml}$ of basal medium or $1 \mathrm{ml}$ of $\mathrm{MO}$ secretions (PCO MO or control MO culture medium respectively) was added (Forneris et al. 2008). Incubation was continued for $3 \mathrm{~h}$, and then the medium was removed and stored at $-20{ }^{\circ} \mathrm{C}$ until $\mathrm{PGE}_{2}$ and nitrites release contents were measured.

\section{Obtaining and incubation of ovarian cells}

The procedures for harvesting and culturing the granulose cells have been described previously (Erickson \& Hsueh 1978, Aguado \& Ojeda 1984). Briefly, granulosa cells from PCO and control ovaries were harvested in RPMI 1640 medium, supplemented with $0.2 \%$ BSA fraction $\mathrm{V}, \mathrm{N}$-2-hydroxyethylpiperazine- $\mathrm{N}^{\prime}$-2-ethanesulfonic acid (HEPES) (10 mM) and EGTA $(6.8 \mathrm{mM})$ by needle puncturing of the follicles. The suspension was centrifuged at $100 \mathrm{~g}$ for $10 \mathrm{~min}$, and the cell pellet was washed in RPMI medium containing penicillin $(50 \mathrm{U} / \mathrm{ml})$ and streptomycin $(50 \mu \mathrm{g} / \mathrm{ml})$. After viability determination by a trypan blue exclusion test, the cells were plated at $3 \times 10^{5}$ viable cells/tube containing $1 \mathrm{ml}$ of RPMI 1640 medium supplemented with androstenedione $\left(10^{-7} \mathrm{M}\right)$, L-glutamine (2 $\mathrm{mM})$, penicillin $(50 \mathrm{U} / \mathrm{ml})$, streptomycin $(50 \mu \mathrm{g} / \mathrm{ml})$ and ovine FSH $(10 \mathrm{ng} / \mathrm{ml})$. Androstenedione was included in all cultures and served as an aromatase substrate (Erickson \& Hsueh 1978). The cells were cultured in a humidified $95 \% \mathrm{v} / \mathrm{v}$ air and $5 \% \mathrm{v} / \mathrm{v} \mathrm{CO}_{2}$ incubator at $37^{\circ} \mathrm{C}$ for $24 \mathrm{~h}$. At the end of this period, the medium was discarded and replaced by fresh medium with antibiotics or $\mathrm{MO}$ secretions. The incubation was continued for $24 \mathrm{~h}$ and then the medium was stored at $-20{ }^{\circ} \mathrm{C}$ until assayed for estradiol release. After harvesting granulosa cells by needle puncturing of the follicles, the corpora lutea were removed, and the residual ovarian tissue, which is considered to be enriched in interstitial cells, was dissociated in $2 \mathrm{ml}$ of RPMI medium containing $0.4 \% \mathrm{w} / \mathrm{v}$ collagenase type $\mathrm{XI}$ (Sigma-Aldrich Co.) and $0.1 \%$ BSA fraction V (SigmaAldrich Co.) by stirring at $37^{\circ} \mathrm{C}$ for $30 \mathrm{~min}$ in a metabolic shaking water bath and assisted by repeatedly drawing tissue fragments into a siliconized pipette. Five minutes before finishing the procedure, $0.001 \%$ of deoxyribonuclease type I (DNase I) (Sigma) was added. Subsequently, the digest was filtered through a nylon mesh and the suspension was centrifuged at $100 \mathrm{~g}$ for $10 \mathrm{~min}$. The cell pellet was washed twice in RPMI medium containing penicillin $(50 \mathrm{U} / \mathrm{ml})$ and streptomycin $(50 \mu \mathrm{g} / \mathrm{ml})$, centrifuged as described above, and finally resuspended in the same medium. $5 \times 10^{5}$ cells were cultured in a humidified $95 \% \mathrm{v} / \mathrm{v}$ air and $5 \% \mathrm{v} / \mathrm{v} \mathrm{CO}_{2}$ incubator at $37{ }^{\circ} \mathrm{C}$ for $24 \mathrm{~h}$. At the end of this period, the medium was removed and replaced by fresh medium with antibiotics or $\mathrm{MO}$ secretions, and the cells were cultured for an additional $24 \mathrm{~h}$. Afterwards, the culture medium was stored at $-20^{\circ} \mathrm{C}$ until assayed for androstenedione release.

\section{Steroid assays}

Estradiol and androstenedione released in the media from the culture of granulosa and interstitial cells, respectively, were determined by RIA using specific antisera as described previously (Forneris \& Aguado 2002). The assays sensitivities were $<12$ fmole/tube for estradiol and $0.02 \mathrm{ng} / \mathrm{ml}$ for androstenedione. For all steroids, the inter- and intra-assay coefficients of variation $(\mathrm{CV})$ were $<10 \%$.

\section{Nitrite assay}

Liquid incubations of ovaries from control and PCO rats were removed and analysed for $\mathrm{NO}$ by assaying nitrites, which is a stable product of $\mathrm{NO}$ oxidation, using the Griess reagent; the absorbance was read at $540 \mathrm{~nm}$ (Egami \& Taniguchi 1974). The intra-assay $\mathrm{CV}$ were $<10 \%$. The results were expressed as micromoles of nitrite per millilitre $(\mu \mathrm{mol} / \mathrm{ml})$.

\section{Histological studies}

After incubation with basal medium or MO secretions, the ovaries were fixed in Bouin's solution. The samples were dehydrated in a graded series of ethanol and embedded in paraffin. Sections $5 \mu \mathrm{m}$ in thickness were obtained using a Microm HM 325 rotation microtome and stained with hematoxylin-eosin. Histological analysis was carried out using a computer-assisted image analysis system consisting of an Olympus BX-40 binocular microscope. The images were 
captured by a Sony SSC-DC5OA camera and processed with Image Pro Plus 5.0 Software (Media Cybernetics Inc., Silver Spring, MD, USA) under control of a Pentium IV computer.

\section{Identification of apoptotic nuclei by TUNEL assay}

Apoptotic nuclei were identified in ovarian tissue using the DeadEnd Colorimetric TUNEL System (Promega) according to the manufacturer's protocol. Briefly, nuclear DNA fragmentation was assessed in $5 \mu \mathrm{m}$ thick sections of ovarian tissue mounted on silane-coated slides, deparaffinized with xylene and then treated with a graded series of ethanol (100, $95,85,70$, and $50 \%(\mathrm{v} / \mathrm{v}))$ and rehydrated in PBS $(\mathrm{pH} 7.5)$. Tissues were then treated with proteinase $\mathrm{K}$ solution for permeabilization and then refixed with $4 \%$ paraformaldehyde solution. Slides were then treated with recombinant terminal deoxynucleotidyl transferase $(\mathrm{TdT})$ reaction mix and incubated in a humidified chamber at $37^{\circ} \mathrm{C}$ for $1 \mathrm{~h}$. The reaction was terminated by immersing the slides in $2 \times$ saline-sodium citrate (SSC) solution for $15 \mathrm{~min}$ at room temperature. After blocking the endogenous peroxidases activity (by $0.3 \%$ hydrogen peroxide), slides were washed with PBS and then incubated with streptavidin horseradish peroxidase solution for $30 \mathrm{~min}$ at room temperature. Afterwards, the slides were incubated for $10 \mathrm{~min}$ with $3,3^{\prime}$-diaminobenzidine (DAB) as chromogen substrate. The sections were counterstained with hematoxylin, dehydrated, mounted and coverslipped. For negative control, incubation with TdT was omitted and the positive control was prepared by treating cells on a separate slide with DNase I. Cells showing dark brown staining from the colorimetric reaction were considered as positive for DNA fragmentation.

The results of the TUNEL assay were evaluated according to the signal intensity as negative $(-)$ and positive $(+)$. TUNEL positive staining was examined in ten consecutive areas from five independent ovarian sections. A total of 50 fields, from control and treated groups, were analysed. The number of TUNEL-positive follicles with apoptotic cells was counted in independent ovarian cross-sections from three different rats under microscope at $100 \times$ objective.

\section{Western blot analysis for iNOS}

Ovaries were homogenized in Tris-HCL $50 \mathrm{nM}(\mathrm{pH} 7.8)$ containing protease inhibitors. Protein was measured by the method of Lowry et al. (1951). $40 \mathrm{mg}$ of proteins were mixed with $10 \mathrm{ml}$ of sample buffer $(125 \mathrm{mM}$ Tris- $\mathrm{HCl}, \mathrm{pH} 6.8$, $4 \%$ SDS, $0.5 \mathrm{mM}$ DTT, $0.02 \%$ bromophenol blue and $20 \%$ glycerol), boiled for 2-3 min and loaded into 8\% SDS-PAGE gel. Protein molecular mass markers were always loaded on each gel. The separated proteins were transferred to PVDF membranes (Polyscreen NEF 1000, NEN Life Science Products, Boston, MA, USA) using a blot transfer system (Bio-Rad). After being blocked overnight with 5\% BSA-TBS solution $(20 \mathrm{mM}$ Tris, $500 \mathrm{mM} \mathrm{NaCl}, \mathrm{pH} 7.5$ ) at $48^{\circ} \mathrm{C}$, membranes were incubated with a primary rabbit anti-iNOS polyclonal antibody solution (Santa Cruz Biotechnologies) (1:1000 dilution) for $1 \mathrm{~h}$ at room temperature. $\beta$-actin expression was measured as a control for protein loading using a rabbit polyclonal antibody.
After washing three times with TBS $(0.1 \%$ Tween $20,100 \mathrm{mM}$ Tris- $\mathrm{HCl}, \mathrm{pH} 7.5,150 \mathrm{mM} \mathrm{NaCl}$ ), the membranes were incubated with an anti-rabbit IgG secondary antibody linked to peroxidase for $1 \mathrm{~h}$ at room temperature. The membranes were washed and the colour was developed using a Vectastain ABC detection system (Vector Laboratories, Burlingame, CA, USA).

\section{prostaglandin $E_{2} R I A$}

$\mathrm{PGE}_{2}$ was determined by RIA as it has been previously reported (Motta et al. 1999). $\mathrm{PGE}_{2}$ was quantified in incubation medium from ovary, and in ovary homogenate from PCO and control rats. To extract $\mathrm{PGE}_{2}$, the samples were first acidified to $\mathrm{pH} 3.0$ with $1 \mathrm{M} \mathrm{HCl}$ and then extracted three times with $1 \mathrm{ml}$ of ethyl acetate. The ethyl acetate extracts were dried under an atmosphere of $\mathrm{N}_{2}$ and stored at $-20{ }^{\circ} \mathrm{C}$ until prostaglandin RIA was performed. $\mathrm{PGE}_{2}$ was quantified by using rabbit antiserum from Sigma. The sensitivity was $10 \mathrm{pg} /$ tube and the cross-reactivity was $100 \% \mathrm{PGE}_{2}$ and $<0.1 \%$ with other prostaglandins. Results are expressed as picogram per milligram of tissue or millilitre of medium.

\section{RNA extraction and semiquantitative RT-PCR}

Total RNA was extracted from MO culture using TRIzol reagent. The semi-quantitative analysis of mRNA was performed using a one-step RT-PCR method (Access RT-PCR System, Promega). All components for RT and PCR were assembled in $50 \mu \mathrm{l}$ reactions containing $5 \times$ reaction buffer (10 mM Tris- $\mathrm{HCl}$, pH 8.3, $50 \mathrm{mM} \mathrm{KCl}$ ), $3 \mathrm{mM} \mathrm{MgCl} 2,10 \mathrm{mM}$ dNTP mixture, $1 \mu \mathrm{M}$ of each gene specific primers, $2 \mu \mathrm{g}$ template RNA, 5 units of avian myoblastic virus (AMV) reverse transcriptase and 5 units of Tfl DNA polymerase. The amplification of cDNA was performed under the following conditions: denaturation at $94{ }^{\circ} \mathrm{C}$ for 2 min followed by 35 cycles of denaturation at $94^{\circ} \mathrm{C}$ for $30 \mathrm{~s}$, annealing at $60{ }^{\circ} \mathrm{C}$ for $\mathrm{Bcl} 2, \mathrm{NFkB}$ and GAPDH and at $61{ }^{\circ} \mathrm{C}$ for Bax, during $1 \mathrm{~min}$ and extension at $72{ }^{\circ} \mathrm{C}$ for $2 \mathrm{~min}$. The reaction was completed with a final extension at $72{ }^{\circ} \mathrm{C}$ for $7 \mathrm{~min}$ (thermal cycler). The following primers were used: Bax: (5'-GCGAATTGGAGATGAACTGG-3' sense and 5'-GTGAGCGAGGCGGTGAGGAC$3^{\prime}$ anti-sense), Bcl2(5'-GCAACCGAACGCCCGCTGTG-3' sense and 5'-GTGATGCAGGCCCCCACC-AG-3' antisense), NFkB: (5'-AGCCCAGAAATATGGACCGT-3' sense and 5'-TCGAAATCTGAAGCCTCGCTGT-3' antisense), GAPDH: (5'-GGGCTGCCTTCTCTTGTGAC-3' sense and 5'-CGCCAGTAGACTCCACGACA-3' antisense). The predicted sizes of the PCR-amplified products were 366, 474, 180 and 325 bp for Bax, Bcl2, NFkB and GAPDH respectively. The PCR products were resolved on $2 \%$ agarose gel electrophoresis containing $0.5 \mathrm{mg} / \mathrm{ml}$ GelRed and photographed with a Polaroid camera. Band intensities of RT-PCR products were quantified using NIH Image software. The relative abundance of each band was normalized according to the housekeeping GAPDH gene, calculated as the ratio of the intensity values of each product to that of GAPDH. Thus, results are expressed as mRNA/GAPDH in arbitrary units. 


\section{Statistical analysis}

All data shown are expressed as mean \pm S.E.M.. and analysed using GraphPad Prism 5 (GraphPad Software, San Diego, CA, USA). Significant differences among means were considered at a level of $P<0.05$ and identified by one-way ANOVA and Tukey's test.

\section{Results}

\section{MO secretions action on the ovarian Bax, Bcl2 and NFkB mRNA expressions}

Presented in Fig. 1A are the results of the densitometric analysis of Bax mRNA (an apoptosis promoter) corrected for GADPH expression (relative densitometric units) in PCO and control ovaries incubated with basal medium (basal conditions), control $\mathrm{MO}$ secretions and PCO MO secretions. It is observed that in basal conditions, the Bax mRNA expression of the PCO ovary was not significantly different to that of the control ovary. Incubating control ovaries with either control or PCO MO secretions resulted in a similar Bax mRNA expression in relation to the control ovary in basal conditions. Furthermore, incubation of the PCO ovary with control $\mathrm{MO}$ secretions did not show significant variations in the Bax mRNA expression with respect to the PCO ovary in basal conditions. However, incubation of the PCO ovary with PCO MO secretions presented a significant increase of Bax mRNA expression with respect to the PCO ovary incubated in basal conditions $(P<0.01)$ and therefore also showed a significant increase compared to the respective control ovary $(P<0.001)$.

As shown in Fig. 1B, no differences in the $\mathrm{Bcl} 2$ (an apoptosis inhibitor) mRNA expression were observed between $\mathrm{PCO}$ and control ovaries incubated with either basal medium, PCO

$\mathrm{MO}$ secretions or control $\mathrm{MO}$ secretions. From the data shown in Fig. $1 \mathrm{~A}$ and $\mathrm{B}$, it can be concluded that incubation of PCO ovaries with PCO MO secretions leads to an increase of the $\mathrm{Bax}$ to $\mathrm{Bcl} 2$ ratio with respect to PCO ovaries incubated in basal conditions $(1.49 \pm$ 0.06 vs $1.16 \pm 0.03 ; P<0.05)$ and also to the control ovaries incubated with PCO MO secretions (1.49 \pm 0.06 vs $0.97 \pm 0.03 ; P<0.05)$.

Incubation of PCO ovaries in basal medium shows no significant differences in the NFkB mRNA expression compared to the corresponding control ovaries. Furthermore, after incubating with both control and PCO MO secretions, no variations were observed in the NFkB mRNA expression of the control ovaries compared to the control ovary in basal conditions. However, PCO ovaries incubated with both control and PCO MO secretions presented an increase of the NFkB gene expression compared to PCO ovaries incubated in basal conditions $(P<0.05$ and $P<0.01$ respectively). Likewise, there was also an increase of the gene expression with respect to the corresponding control ovaries incubated with both control and PCO MO secretions, this increase being greater when $\mathrm{PCO}$ ovaries were incubated with $\mathrm{PCO}$ MO secretions $(P<0.05$ for control and $P<0.01$ for $\mathrm{PCO}$ $\mathrm{MO}$ secretions) (Fig. 1C).
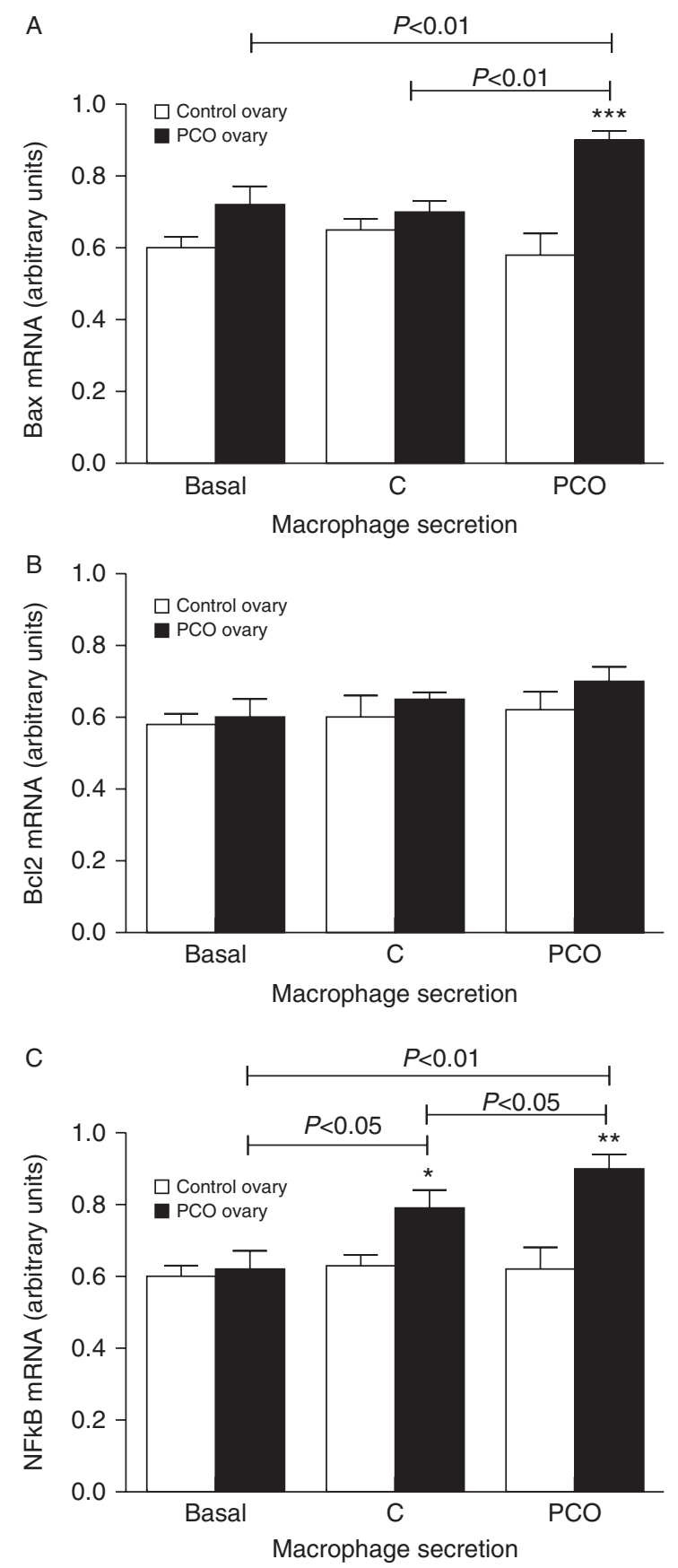

Figure 1 Macrophage secretions on the ovarian (A) Bax mRNA expression, (B) Bcl2 mRNA expression and (C) NFkB mRNA expression. Ovaries from control $(\mathrm{C})$ and polycystic $(\mathrm{PCO})$ rats were stimulated with either basal medium (basal) or culture medium of $\mathrm{C}$ and PCO macrophages (macrophage secretions) for $3 \mathrm{~h}$. Target mRNA was normalized by the level of GAPDH mRNA. Values are mean \pm s.E.M. of three independent experiments, each experiment performed with three $\mathrm{C}$ and three PCO rats. ${ }^{*} P<0.05,{ }^{* *} P<0.01,{ }^{* * *} P<0.001$ compared with respective control. 


\section{$M O$ secretions on the ovarian $\mathrm{PGE}_{2}$ content and release}

The results of the $\mathrm{PGE}_{2}$ content in the ovaries are presented in Fig. 2A. It is observed that under basal conditions, the $\mathrm{PGE}_{2}$ content was significantly increased in the PCO ovary with respect to the control ovary $(P<0.001)$. It is also observed that incubating the control ovaries with both control and PCO MO secretions does not show an appreciable variation of prostaglandin content with respect to ovaries incubated in basal conditions. However, incubation of the PCO ovary with both control and PCO MO secretions showed a significant decrease of $\mathrm{PGE}_{2}$ content with respect to the PCO ovary in basal conditions and also compared to their respective control ovaries $(P<0.001)$, this decrease being more pronounced in the case of the PCO ovary incubated with PCO MO secretions.

As shown in Fig. 2B, under basal conditions, the amount of $\mathrm{PGE}_{2}$ released from the $\mathrm{PCO}$ ovary was
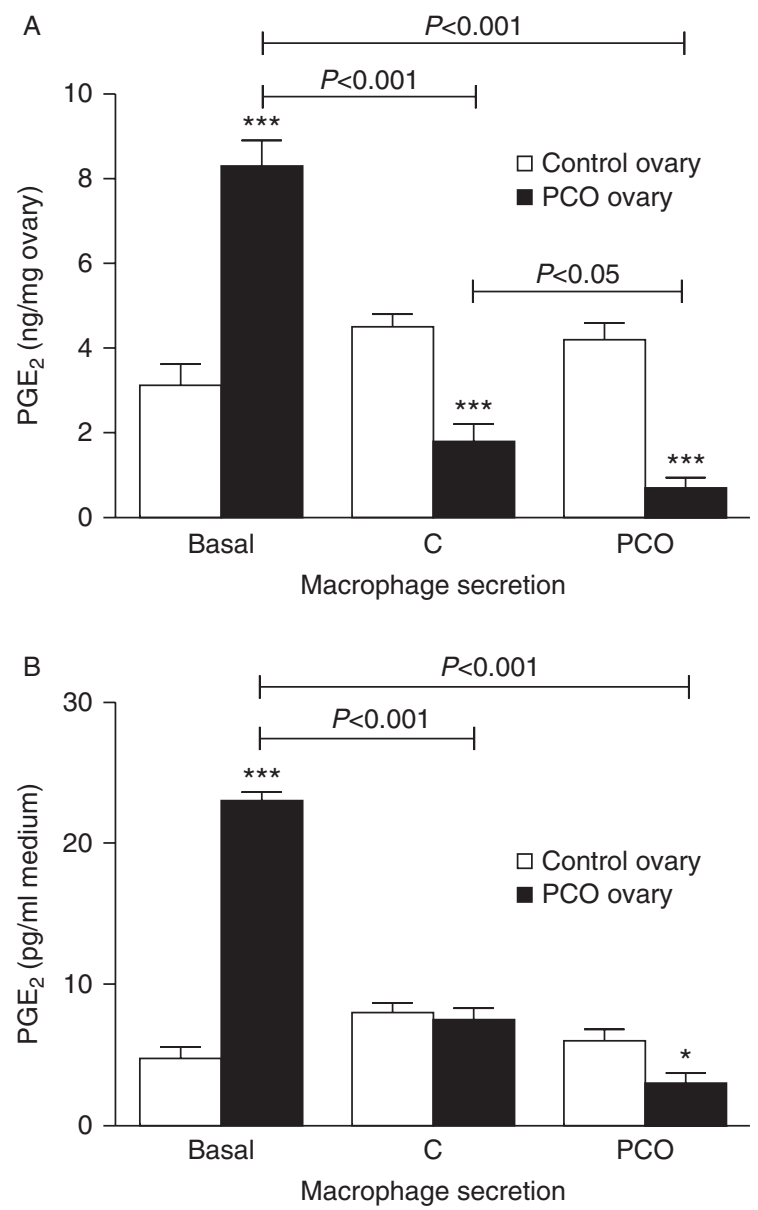

Figure 2 Macrophage secretions on the ovarian (A) prostaglandin $E_{2}$ $\left(\mathrm{PGE}_{2}\right)$ content $(\mathrm{A})$ and release $(\mathrm{B})$. Ovaries from control $(\mathrm{C})$ and polycystic (PCO) rats were stimulated with either basal medium (basal) or culture medium of $\mathrm{C}$ and PCO macrophages (macrophage secretions) for $3 \mathrm{~h}$. Values are mean \pm s.E.M.. of three independent experiments, each experiment performed with three $\mathrm{C}$ and three PCO rats. ${ }^{*} P<0.05,{ }^{* * *} P<0.001$ compared with respective control. significantly increased compared to the control ovary $(P<0.001)$. Incubating the control ovaries with both control and PCO MO secretions resulted in no significant variation in the amount of $\mathrm{PGE}_{2}$ released with respect to control ovaries incubated with basal medium. However, incubation of the PCO ovary with both control and PCO MO secretions showed a significant decrease of $\mathrm{PGE}_{2}$ release with respect to the PCO ovary in basal conditions $(P<0.001)$, this decrease being more pronounced in the case of the PCO ovary incubated with PCO MO secretions. Therefore, incubating the PCO ovary with PCO MO secretions showed a decrease of $\mathrm{PGE}_{2}$ release compared to the corresponding control ovary $(P<0.05)$.

\section{MO secretions on the ovarian nitrite release and iNOS protein expression}

The results of nitrite released from the ovaries are presented in Fig. 3A. The release of nitrites from the PCO ovary incubated in basal conditions showed an increase with respect to the nitrites released by the corresponding control ovary $(P<0.01)$. Stimulating control ovaries with both control and PCO MO secretions resulted in a similar increase of nitrite release compared to the control ovaries in basal condition $(P<0.001)$. Furthermore, incubation of the PCO ovaries with control $\mathrm{MO}$ secretions showed an increase of nitrites released $(P<0.01)$ with respect to basal conditions, while no change was observed when incubating with PCO MO secretions. Thus, incubation of PCO ovaries with PCO MO secretions showed a significant decrease of the nitrite released from the PCO ovaries in relation to the respective control ovary $(P<0.001)$.

The results of iNOS protein expression in the ovaries are shown in Fig. 3B. Immunoblot analysis with an antiiNOS monoclonal antibody demonstrated enhanced levels of iNOS protein expressions in PCO ovaries incubated in basal conditions relative to the corresponding control ovary $(P<0.05)$. Stimulation of the control ovaries with both control and PCO MO secretions did not show changes of the iNOS expression with respect to that in basal conditions, whereas stimulating the PCO ovaries with both secretions resulted in a decrease of the iNOS expression relative to the PCO ovary in basal conditions $(P<0.001)$, this decrease being more important with PCO MO secretions. Therefore, incubating the PCO ovary with PCO MO secretions showed a decrease of iNOS protein compared to the corresponding control ovary $(P<0.001)$.

\section{Effect of MO secretions on the steroids release from ovarian cells}

Incubating with $\mathrm{MO}$ secretions from $\mathrm{PCO}$ as well as from control rats had a stimulatory effect on the androstenedione release from interstitial cells of both control and 

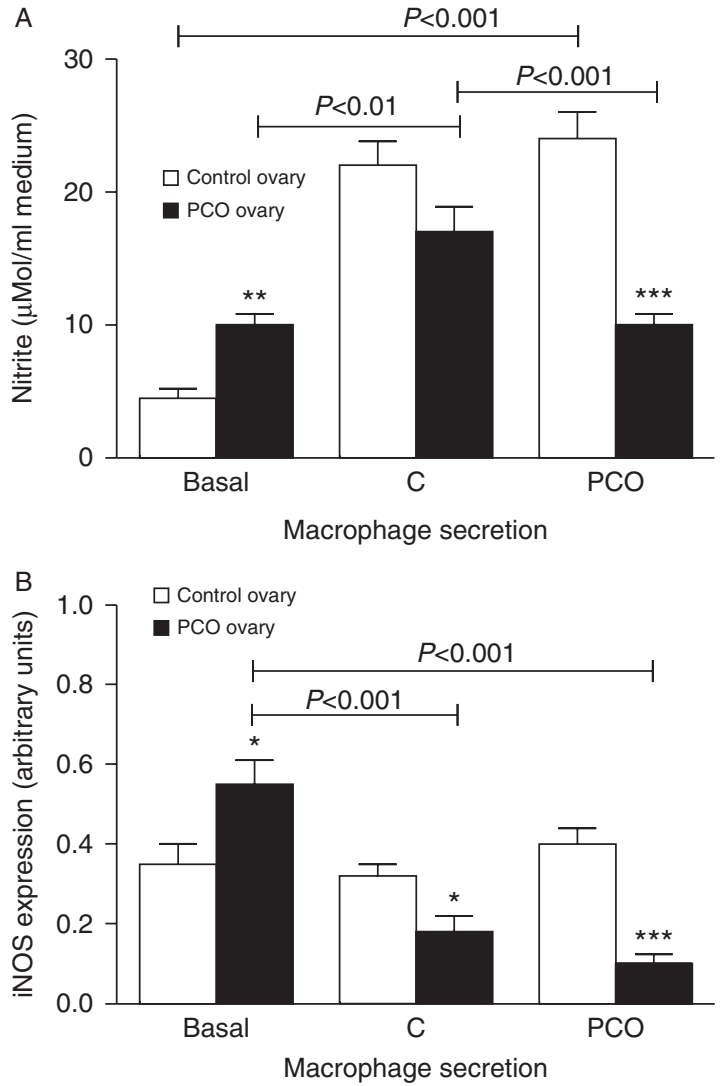

Figure 3 Macrophage secretions on the ovarian (A) nitrite release and (B) iNOS protein expression. Ovaries from control (C) and polycystic (PCO) rats were stimulated with either basal medium (basal) or culture medium of $\mathrm{C}$ and PCO macrophages (macrophage secretions) for $3 \mathrm{~h}$. Values are mean \pm s.E.M.. of three independent experiments, each experiment performed with three $\mathrm{C}$ and three PCO rats. The corresponding graph shows integrated optical density of the bands. ${ }^{*} P<0.05,{ }^{* *} P<0.01,{ }^{* * *} P<0.001$ compared with respective control.

PCO ovaries compared to their respective basal values $(P<0.001)$. In all cases, including basal conditions, PCO ovaries released more androstenedione than control ovaries (Fig. 4A), this difference being greater when stimulated with PCO MO secretions. Figure $4 \mathrm{~B}$ shows that after stimulation with both control and PCO MO secretions, estradiol release from control granulosa cells showed no significant differences compared to basal conditions. However, incubating the PCO granulosa cells with both secretions resulted in a decrease of the estradiol release relative to the cells in basal conditions, and this decrease was more pronounced when PCO granulosa cells were incubated with PCO MO secretions $(P<0.05$ for control and $P<0.01$ for $\mathrm{PCO} \mathrm{MO}$ secretions).

\section{Effect of MO secretions on the ovarian TUNEL staining}

In situ TUNEL analysis was used to detect the presence of apoptotic activity in ovarian sections (Fig. 5).
As expected, in basal conditions, the control ovary showed low or no staining and the absence of cystic follicles. Only a negligible amount of apoptosis in granulosa cells of secondary and antral follicles was observed (Fig. 5A). On the other hand, the PCO ovary showed TUNEL-positive reaction in a few primary follicles and an increased reactivity in secondary and antral follicles, as well as an abundance of cystic follicles, compared to control (Fig. 5B). TUNEL staining was predominantly localized in granulosa cells and, in less extent, on theca cells. It was observed that when incubating with PCO MO secretions, the TUNEL reactivity in secondary and antral follicles of the control ovary increased (Fig. 5E) and even more in secondary and antral follicles of the PCO ovary (Fig. 5F) compared with the respective ovary in basal conditions. TUNEL staining was seen in both granulosa as well as theca cells
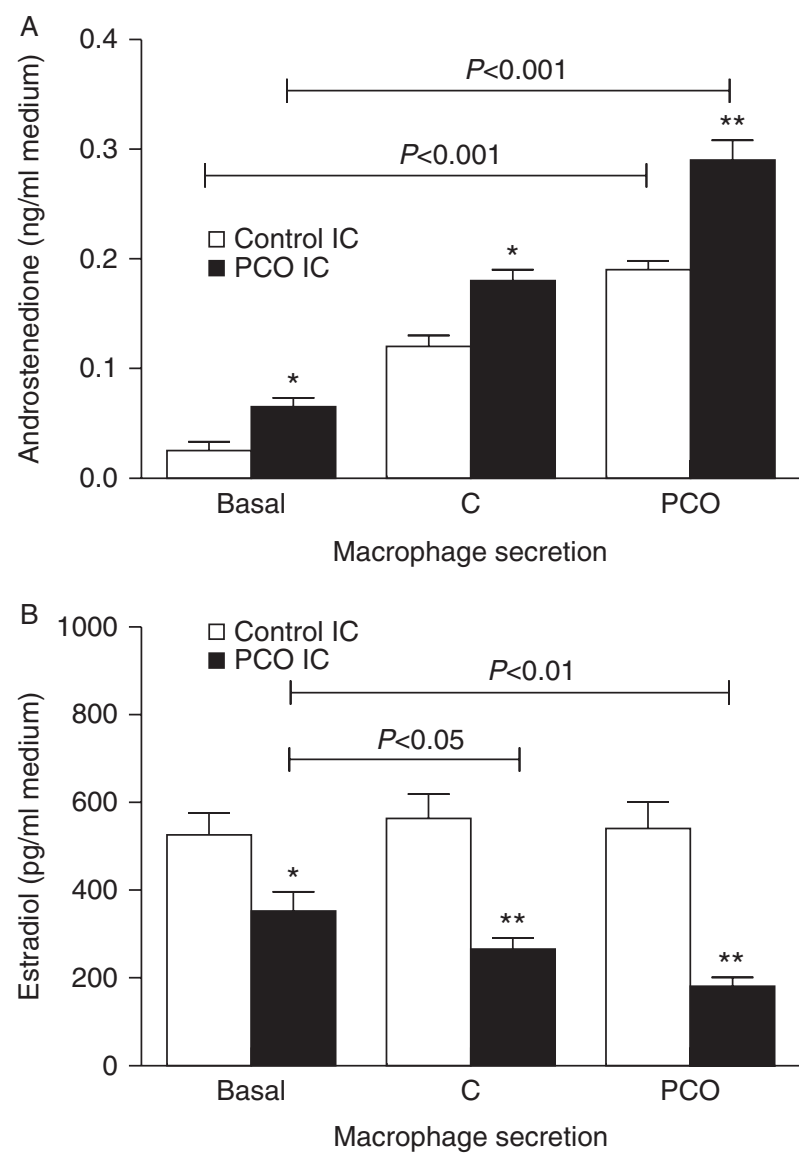

Figure $4(\mathrm{~A})$ Effect of macrophage secretions on the androstenedione release from ovarian cells. Interstitial cells (IC) from control (C) and polycystic (PCO) rats were stimulated with either basal medium (basal) or culture medium of $\mathrm{C}$ and PCO macrophages (macrophage secretions) for 24 h. (B) Effect of macrophage secretions on the estradiol release from ovarian cells. Granulosa cells (GC) from control (C) and polycystic (PCO) rats were stimulated with either basal medium (basal) or culture medium of C and PCO macrophages (macrophage secretions) for $24 \mathrm{~h}$. Values are mean \pm s.E.M.. of three independent experiments, each experiment performed with three $C$ and three PCO rats. ${ }^{* *} P<0.01 ;{ }^{*} P<0.05$ compared with respective control. 

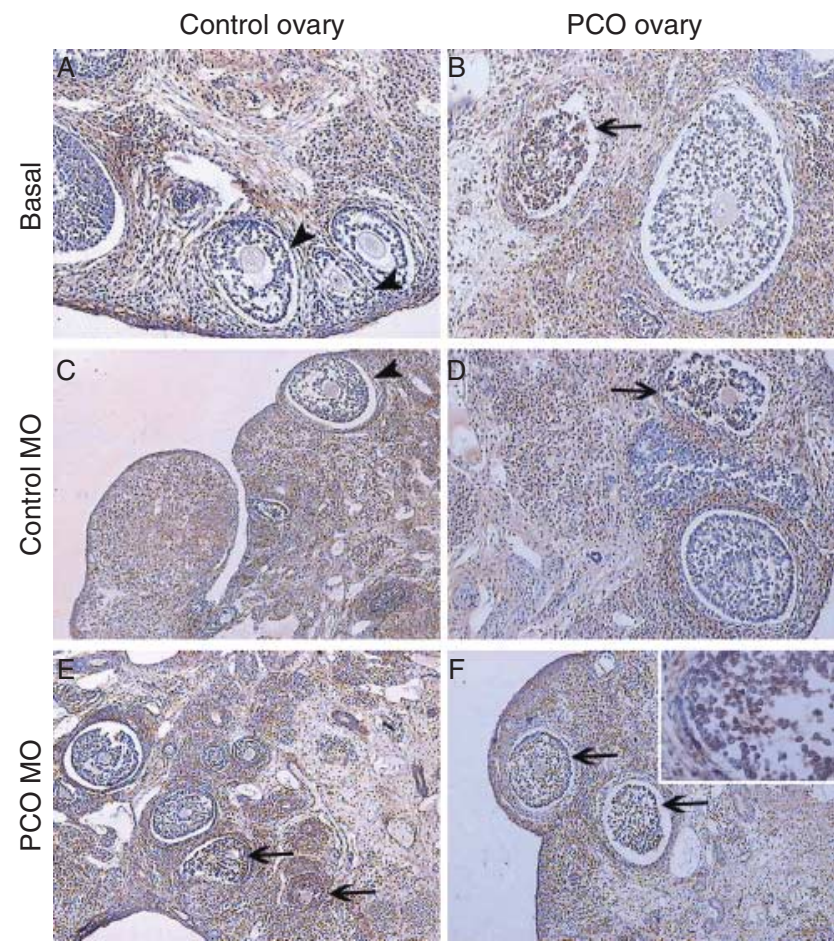

Figure 5 In-situ detection of apoptosis by TUNEL in ovarian sections of control and PCO rats. Representative photomicrographs of control $(\mathrm{A}, \mathrm{C}$ and $\mathrm{D})$ and estradiol valerate exposed $(\mathrm{B}, \mathrm{E}$ and $\mathrm{F})$ rat ovary sections are shown. Ovaries from control and PCO rats were incubated for $6 \mathrm{~h}$ in basal medium (Basal) or macrophage secretions from control (Control MO) and PCO (PCO MO) rats. Nuclear dark brown staining shows a positive reaction. Arrowheads indicate isolated apoptotic cells, and arrows indicate apoptotic follicles. In basal conditions, increased apoptosis on the PCO ovary is evident as compared to negligible apoptosis in the control ovary (A and B). PCO MO secretions increase TUNEL reactivity in the control ovary and even more in the PCO ovary (E and F). Control MO secretions do not modify TUNEL reactivity in the control or PCO ovary compared to respective basal (C and D). TUNEL staining was predominately localized in granulosa cells. Magnification $100 \times$.

in PCO ovaries under stimulation with PCO $\mathrm{MO}$ secretions. The distribution of TUNEL positive reactions in granulosa cells in primary, secondary and antral follicles is illustrated in the Table 1.

\section{Discussion}

Cystic ovarian disease and/or PCOS are reproduction disorders that affect human beings and other species such as bovine, ovine, caprine and porcine (Garverick 1997, Jakimiuk et al. 2002, Silvia et al. 2002, Salvetti et al. 2004, Salvetti et al. 2007). The heterogeneity of the syndrome is reflected in many polycystic ovaries animal models (Mahajan 1988, Salvetti et al. 2004, Baravalle et al. 2006, Francou et al. 2008). Furthermore, EV is one of the most widely used steroids to induce $\mathrm{PCO}$ in rats (Brawer et al. 1986, Rosa-e-Silva et al. 2003). On this basis, in the current work, the effect of MO secretions on the polycystic ovarian apoptosis has been studied to gain further knowledge on the mechanisms determining PCO. The results show that $\mathrm{MO}$ secretions induce apoptosis in the PCO ovary.

In the ovary, the mechanisms underlying decisions of life and death involve cross-dialogue between proapoptotic and pro-survival molecules through fetal and adult life, which are carried out by several molecular pathways, out of which the Bcl2 family, TNF and caspases proteins appear to be important players. The Bax/ $\mathrm{Bcl} 2$ ratio, which is thought to be a critical determinant of cell fate (a low ratio favours extended survival of cells, whereas a high ratio accelerates cell death) (Rueda et al. 1999, Tilly 2001, Skarzynski et al. 2005, Bas et al. 2011), was significantly higher in the PCO than in the control ovary incubated with PCO MO secretions, suggesting that these secretions may be involved in an imbalance among apoptotic and proapoptotic family members in the PCO ovary. In this sense, the NFkB mRNA expression was increased in the PCO ovary after incubation with the PCO MO secretions. It is known that the activation of this transcription factor, which induces the transcription of downstream target genes involved in the inflammatory and apoptotic process (Perkins 2007), is induced by TNF in rat granulosa cells through phosphorylation of $\mathrm{IkB}$ (Gonzalez-Navarrete et al. 2007). Considering the proapoptotic role for TNF in reproductive tissues (Kaipia et al. 1996, Hussein 2005, Haider \& Knofler 2009) and having observed that secretions from spleen $\mathrm{MO}$ of $\mathrm{PCO}$ rats contain more TNF than secretions from control $\mathrm{MO}$ (Figueroa et al. 2012), the induction of NFkB mRNA expression in the PCO ovary after incubation with control MO secretions, which was even more accentuated with PCO MO secretions, could be associated, at least to some extent, to the TNF levels of the MO secretions. In addition, after incubation with PCO MO secretions, an increase of the apoptotic nuclei number in

Table 1 In situ detection of apoptosis by TUNEL in ovarian sections from control and PCO rats treated, or untreated, with macrophages secretions.

\begin{tabular}{lcccc}
\hline & \multicolumn{4}{c}{ Follicles } \\
\cline { 2 - 5 } Group & Primary & Secondary & Antral & Cystic \\
\hline Control (Basal) & - & - & $+/-$ & $\mathrm{Ab}$ \\
PCO (Basal) & + & ++ & ++ & ++ \\
Control+MO PCO & - & + & ++ & $\mathrm{Ab}$ \\
PCO+MO PCO & ++ & +++ & +++ & +++ \\
\hline
\end{tabular}

Adult cycling Holtzman control and PCO rats (injected with $2 \mathrm{mg}$ of estradiol valerate) were sacrificed at estrus day. Ovaries from control and PCO rats were incubated for $6 \mathrm{~h}$ in basal medium (Basal) and macrophage secretions from PCO rats (MO PCO). Then, the ovaries were collected and processed for detection of apoptosis by TUNEL. Intensity of the positive TUNEL reaction: $(-)$ negative; $(+/-)$ weak positive; $(+)$ positive; $(++)$ strong positive; $(+++)$ strong positive including theca and stromal cells; $\mathrm{Ab}$, absence of respective type of follicle. 
the granulosa cells of the PCO ovary was detected by TUNEL staining. All of these findings suggest that PCO $\mathrm{MO}$ secretions induce apoptosis in the PCO ovary. Furthermore, immune cells play an important role in the pathology of PCOS, as suggested by the high concentration of white cells in the PCO ovary (Bukulmez \& Arici 2000, Wu et al. 2004, Wu et al. 2007). Thus, resident $\mathrm{MO}$ populations could possibly modulate the cell death in the PCO ovary.

In the ovary, resident $\mathrm{MO}$ and other white cells, as well as follicular granulosa and theca cells, are known to produce prostaglandins (Takaya et al. 1997). In particular, $\mathrm{PGE}_{2}$ has been shown to mediate the ovarian follicle growth in the rat in vivo (El-Nefiawy et al. 2005). In the present work, it was found that the content of $\mathrm{PGE}_{2}$ in the PCO ovary incubated with basal medium was higher than in control ovary, as it was also observed with the $\mathrm{PGE}_{2}$ release. This agrees with results from other authors who found an increased $\mathrm{PGE}_{2}$ release from dehydroepiandrosterone- or letrozole- induced polycystic ovaries in rats and also from polycystic ovary granulosa cells collected from women (Navarra et al. 1996, Jabbour et al. 2009, Rezvanfar et al. 2011). Interestingly, both control and PCO MO secretions decreased the $\mathrm{PGE}_{2}$ content of the PCO ovary, and this decrease was more pronounced with $\mathrm{PCO}$ than with control $\mathrm{MO}$ secretions. It is known that NO, which is produced by the resident and infiltrating ovarian $\mathrm{MO}$, and also by ovarian cells (Bukulmez \& Arici 2000, Wu et al. 2004, Wu et al. 2007), stimulates cyclooxygenase-2 (COX-2) activity, which is the rate-limiting step in prostaglandin synthesis (Chandrasekharan \& Simmons 2004). Therefore, the fact that iNOS protein expression and nitrite levels follow a similar pattern than the $\mathrm{PGE}_{2}$ content suggests that $\mathrm{PGE}_{2}$ synthesis can be modified by PCO MO secretions.

The exact role of prostaglandins during apoptosis remains unclear. On the other hand, $\mathrm{PGE}_{2}$ promotes survival of pathological cells by inhibiting apoptosis (heng et al. 1998, Rask et al. 2006), as well as death cells by pro-apoptotic effects (Bowolaksono et al. 2008). We have observed an inverse relationship between $\mathrm{PGE}_{2}$ content and apoptosis of the PCO ovary after stimulation with PCO MO secretions, where a lower ovarian $\mathrm{PGE}_{2}$ content and release and a higher apoptotic nuclei numbers were found compared with the effect induced by control $\mathrm{MO}$ secretions. It is also known that $\mathrm{PGE}_{2}$ suppresses cell death induced by TNF in ovarian bovine luteal cells (Bowolaksono et al. 2008), and Kunisch et al. (2009) have shown that $\mathrm{PGE}_{2}$ can act as a negative feedback molecule in the signalling pathway linking TNF to pro-destructive matrix metalloproteinase (MMP1) production in fibroblast cells. In addition, a high ovarian matrix metalloproteinase-2 (MMP2) has been found to be increased in PCO rats compared with healthy controls (Rezvanfar et al. 2014). Therefore, because our previous results show that the TNF $\alpha$ level of PCO MO secretions is higher than control MO secretions (Figueroa et al. 2012), it is conceivable that the low $\mathrm{PGE}_{2}$ content of the PCO ovary stimulated with those secretions can contribute to apoptosis promotion.

Moreover, an apoptotic role of androgen has been recognized in reproductive tissues. In this sense, global knockout of the androgen receptor in female mice leads to reduced fertility, with reduced numbers of antral follicles and increased granulose cells apoptosis (Shiina et al. 2006, Walters et al. 2008, Tyndall et al. 2012). We have previously shown that PCO MO secretions decrease the conversion of androstenedione to estradiol in the PCO ovary, leading to an increase of androstenedione (Figueroa et al. 2012). This was also observed in the current study when PCO ovarian cells were incubated with PCO MO secretions, where an increase of androstenedione release from interstitial cells and a decrease of estradiol release from granulosa cells occurred. This effect can be attributed, at least in part, to the high TNF $\alpha$ content of PCO MO secretions. It has been reported that TNF $\alpha$ activates transcription of an inducible repressor form of $3^{\prime}, 5^{\prime}$-cyclic adenosine $5^{\prime}$-monophosphate-responsive element binding modulator and represses P450 aromatase in ovarian rat granulosa cells (Morales et al. 2006). In addition, we have previously observed an increase of IL6 mRNA expression in PCO MO compared with control MO, which was even greater after treatment with testosterone (Figueroa et al. 2012), indicating that IL6 mRNA abundance seems to be modulated, as it was observed with TNF $\alpha$, by testosterone environment. Because an enhanced IL6 production may attenuate estradiol production, partially by inhibiting the expression of aromatase mRNA in rat granulosa cells (Tamura et al. 2000), it is possible that the increased IL6 expression of PCO MO may contribute to the steroidogenic ability of the $\mathrm{MO}$ secretions to decrease the androstenedione conversion to estradiol in the PCO ovary.

Moreover, the low $\mathrm{PGE}_{2}$ content and $\mathrm{NO}$ production found in the PCO ovaries stimulated with $\mathrm{MO}$ secretions could contribute to the androgen environment. $\mathrm{PGE}_{2}$ stimulates Cyp19 expression, the key gene of estrogen biosynthesis, in rat granulosa cells (Cai et al. 2007). In relation to $\mathrm{NO}$, it is known that the in vitro synthesis of estradiol is inversely regulated by $\mathrm{NO}$ in ovarian rat cells (Dave et al. 1997) and also in human granulosa-luteal cells cultures, the NO being capable of directly inhibiting the activity of aromatase or indirectly decreasing the levels of the mRNA of the enzyme (Snyder et al. 1996).

Considering the present results and knowing that testosterone stimulates the TNF $\alpha$ and IL 6 production by $\mathrm{MO}$, it is reasonable to suggest that the increase of androgens stimulated in ovarian cells by PCO MO secretions could in turn stimulate the cytokine production from $\mathrm{MO}$, thus maintaining an apoptotic vicious cycle in the PCO ovary. 
Despite the bidirectional relationship between proinflammatory cytokines and the androgen excess in PCOS is still unclear, our results suggest that the detrimental effect of up-regulation of proinflammatory cytokines of spleen MOs could contribute to explain the lack or loss of reproductive capacities observed in PCOS. Also, the possibility that $\mathrm{MO}$ secretions released into the general circulation can act on hypothalamic-pituitary sites, and subsequently produce changes in the ovary, cannot be discard.

\section{Supplementary data}

This is linked to the online version of the paper at http:// dx.doi.org/10.1530/REP-15-0216.

\section{Declaration of interest}

The authors declare that there is no conflict of interest that could be perceived as prejudicing the impartiality of the research reported.

\section{Funding}

This work was supported by grant 9302 from the National University of San Luis, Argentina.

\section{References}

Aguado LI \& Ojeda SR 1984 Ovarian adrenergic nerves play a role in maintaining preovulatory steroid secretion. Endocrinology 114 1944-1946. (doi:10.1210/endo-114-5-1944)

Amato G, Conte M, Mazziotti G, Lalli E, Vitolo G, Tucker AT, Bellastella A, Carella C \& Izzo A 2003 Serum and follicular fluid cytokines in polycystic ovary syndrome during stimulated cycles. Obstetrics and Gynecology 101 1177-1182. (doi:10.1016/S0029-7844(03)00233-3)

Baravalle C, Salvetti NR, Mira GA, Pezzone N \& Ortega HH 2006 Microscopic characterization of follicular structures in letrozole induced polycystic ovarian syndrome in the rat. Archives of Medical Research 37 830-839. (doi:10.1016/j.arcmed.2006.04.006)

Bas D, Abramovich D, Hernandez F \& Tesone M 2011 Altered expression of $\mathrm{Bcl} 2$ and $\mathrm{Bax}$ in follicles within dehydroepiandrosterone-induced polycystic ovaries in rats. Cell Biology International 35 423-429. (doi:10.1042/CBI20100542)

Besedovsky HO \& del Rey A 1996 Immune-neuro-endocrine interactions: facts and hypotheses. Endocrine Reviews 17 64-102. (doi:10.1210/edrv17-1-64)

Bilbo SD \& Klein SL 2012 The neuroendocrine-immune axis in health and disease. Hormones and Behavior 62 187-190. (doi:10.1016/j.yhbeh. 2012.06.005)

Bowolaksono A, Nishimura R, Hojo T, Sakumoto R, Acosta T \& Okuda K 2008 Anti-apoptotic roles of prostaglandin E2 and F2 $\alpha$ in bovine luteal steroidogenic cells. Biology of Reproduction 79 310-317. (doi:10.1095/ biolreprod.107.066084)

Brawer JR, Muñoz J \& Farookhi R 1986 Development of the polycystic ovarian condition (PCO) in the estradiol valerate-treated rat. Biology of Reproduction 35 647-655. (doi:10.1095/biolreprod35.3.647)

Bukulmez O \& Arici A 2000 Leukocytes in ovarian function. Human Reproduction Update 6 1-15. (doi:10.1093/humupd/6.1.1)

Cai Z, Kwintkiewicz J, Young ME \& Stocco C 2007 Prostaglandin E2 increases cyp19 expression in rat granulosa cells: implication of GATA-4. Molecular and Cellular Endocrinology 263 181-189. (doi:10.1016/ j.mce.2006.09.012)
Chandrasekharan NV \& Simmons DL 2004 The cyclooxygenases. Genome Biology 5 241-248. (doi:10.1186/gb-2004-5-9-241)

Chen Q, Yano T, Matsumi H, Osuga Y, Yano N, Xu J, Wada O, Koga K, Fujiwara T, Kugu K et al. 2005 Cross-Talk between Fas/Fas ligand system and nitric oxide in the pathway subserving granulosa cell apoptosis: a possible regulatory mechanism for ovarian follicle atresia. Endocrinology 146 808-815. (doi:10.1210/en.2004-0579)

Das M, Djahanbakhch O, Hacihanefioglu B, Saridogan E, Ikram M, Ghali L, Raveendran M \& Storey A 2008 Granulosa cell survival and proliferation are altered in polycystic ovary syndrome. Journal of Clinical Endocrinology and Metabolism 93 881-887. (doi:10.1210/jc. 2007-1650)

Dave S, Farrance DP \& Whitehead SA 1997 Evidence that nitric oxide inhibits steroidogenesis in cultured rat granulosa cells. Clinical Science 92 277-284. (doi:10.1042/cs0920277)

Egami F \& Taniguchi S 1974 Methods of Enzymatic Analysis, 2nd edn. New York, NY: Academic Press.

El-Nefiawy N, Abdel-Hakim K, Kanayama N \& Terao T 2005 Role of prostaglandin E2 receptor subtypes in ovarian follicle growth in the rat in vivo. Correlation with interleukin-8 and neutrophils. Correlation with interleukin-8 and neutrophils. Histology and Histopathology 20 825-831.

Erickson GF \& Hsueh AJ 1978 Stimulation of aromatase activity by follicle stimulating hormone in rat granulosa cells in vivo and in vitro. Endocrinology 102 1275-1282. (doi:10.1210/endo-102-4-1275)

Figueroa F, Davicino R, Micalizzi B, Oliveros L \& Forneris M 2012 Macrophage secretions modulate the steroidogenesis of polycystic ovary in rats: effect of testosterone on macrophage pro-inflammatory cytokines. Life Science 90 733-739. (doi:10.1016/j.Ifs.2012.03.019)

Forneris ML \& Aguado LI 2002 Neonatal superior ovarian nerve transection disturbs the cyclic activity of the female rats. Journal of Steroid Biochemistry and Molecular Biology 82 75-82. (doi:10.1016/S09600760(02)00149-8)

Forneris ML, Aguado LI \& Oliveros LB 2003 A neuroimmune regulation at peripheral level on the steroidogenesis of polycystic ovary in rats. Cellular and Molecular Biology 49 965-971.

Forneris M, Rosales E, Ciuffo G \& Oliveros L 2008 Testosterone environment of splenocytes modifies the steroidogenesis of polycystic ovary in rats. Hormone and Metabolic Research 40 239-244. (doi:10. 1055/s-2007-1022545)

Francou M, Durdos M, Salvetti NR, Baravalle C, Rey F \& Ortega HH 2008 Characterization of pituitary cell populations in rats with induced polycystic ovaries. Cells, Tissues, Organs 188 310-319. (doi:10.1159/ 000123202)

Gallinelli A, Ciaccio I, Giannella L, Salvatori M, Marsella T \& Volpe A 2003 Correlations between concentrations of interleukin-12 and interleukin-13 and lymphocyte subsets in the follicular fluid of women with and without polycystic ovary syndrome. Fertility and Sterility 79 1365-1372. (doi:10.1016/S0015-0282(03)00344-3)

Garverick HA 1997 Ovarian follicular cysts in dairy cows. Journal of Dairy Science 80 995-1004. (doi:10.3168/jds.S0022-0302(97)76025-9)

Gómez $R$, Ferrero $H$, Delgado-Rosas $F$, Gaytan $M$, Morales $C$, Zimmermann RC, Simón C, Gaytan F \& Pellicer A 2011 Evidences for the existence of a low dopaminergic tone in polycystic ovarian syndrome: implications for OHSS development and treatment. Journal of Clinical Endocrinology and Metabolism 96 2484-2492. (doi:10.1210/jc.2011-0075)

Gonzalez-Navarrete F, Eisner V, Morales P, Castro O, Pommer R, Quiroga C, Lavandero S \& Devoto L 2007 Tumor necrosis factor- $\alpha$ activates nuclear factor- $\kappa \mathrm{B}$ but does not regulate progesterone production in cultured human granulosa luteal cells. Gynecological Endocrinology 23 377-384. (doi:10.1080/09513590701444839)

Goodarzi MO, Dumesic DA, Chazenbalk G \& Azziz R 2011 Polycystic ovary syndrome: etiology, pathogenesis and diagnosis. Nature Reviews. Endocrinology 7 219-231. (doi:10.1038/nrendo.2010.217)

Greenfeld CR, Roby KF, Pepling ME, Babus JK, Terranova PF \& Flaws JA 2007 Tumor necrosis factor (TNF) receptor type 2 is an important mediator of TNF $\alpha$ function in the mouse ovary. Biology of Reproduction 76 224-231. (doi:10.1095/biolreprod.106.055509)

Haider S \& Knofler M 2009 Human tumor necrosis factor: physiological and pathological roles in placenta and endometrium. Placenta 30 111-123. (doi:10.1016/j.placenta.2008.10.012) 
Hussein MR 2005 Apoptosis in the ovary: molecular mechanisms. Human reproduction 11 162-178. (doi:10.1093/humupd/dmi001)

Jabbour HN, Sales KJ, Catalano RD \& Norman JE 2009 Inflammatory pathways in female reproductive health and disease. Reproduction 138 903-919. (doi:10.1530/REP-09-0247)

Jakimiuk AJ, Weitsman SR, Yen HW, Bogusiewicz M \& Magoffin DA 2002 Estrogen receptor $\alpha$ and $\beta$ expression in theca and granulosa cells from women with polycystic ovary syndrome. Journal of Clinical Endocrinology and Metabolism 87 5532-5538. (doi:10.1210/jc.2002020323)

Kaipia A, Chun SY, Eisenhauer K \& Hsueh A 1996 T Tumor necrosis factor- $\alpha$ and its second messenger, ceramide, stimulate apoptosis in cultured ovarian follicles. Endocrinology 137 4864-4870. (doi:10.1210/endo. 137.11.8895358)

Krysko DV, Diez-Fraile A, Criel G, Svistunov AA, Vandenabeele P \& D'Herde K 2008 Life and death of female gametes during oogenesis and folliculogenesis. Apoptosis 13 1065-1087. (doi:10.1007/s10495-0080238-1)

Kunisch E, Jansen A \& Kojima F 2009 Prostaglandin E2 differentially modulates proinflammatory/prodestructive effects of TNF-a on synovial fibroblasts via specific E prostanoid receptors/cAMP. Journal of Immunology 183 1328-1336. (doi:10.4049/jimmunol.0900801)

Kuroda E \& Yamashita U 2003 Mechanisms of enhanced macrophagemediated prostaglandin E2 production and its suppressive role in Th1 activation in Th2-dominant BALB/c mice. Journal of Immunology $\mathbf{1 5}$ 757-764. (doi:10.4049/jimmunol.170.2.757)

Lara HE, Ferruz JL, Luza S, Bustamante DA, Borges Y \& Ojeda SR 1993 Activation of ovarian sympathetic nerves in polycystic ovary syndrome. Endocrinology 133 2696-2703. (doi:10.1210/endo.133.6.7902268)

Lin Y, Kokontis J, Tang F, Godfrey B, Liao S, Lin A, Chen Y \& Xiang J 2006 Androgen and its receptor promote Bax-mediated apoptosis. Molecular and Cellular Biology 26 1908-1916. (doi:10.1128/MCB.26.5.19081916.2006)

Lowry OH, Rosebrough NJ, Farr AL \& Randall RJ 1951 Protein measurement with the Folin phenol reagent. Journal of Biological Chemistry 193 265-275.

Mahajan DK 1988 Polycystic ovarian disease: animal models. Endocrinology and Metabolism Clinics of North America 17 705-732.

Morales V, Gonzalez-Robayna I, Santana MP, Hernandez I \& Fanjul LF 2006 Tumor necrosis factor- $\alpha$ activates transcription of inducible repressor form of $3^{\prime}, 5^{\prime}$-cyclic adenosine $5^{\prime}$-monophosphate-responsive element binding modulator and represses P450 aromatase and inhibin $\alpha$-subunit expression in rat ovarian granulosa cells by a p44/42 mitogenactivated protein kinase depending mechanism. Endocrinology 147 5932-5939. (doi:10.1210/en.2006-0635)

Motta AB, Estevez A \& Gimeno MF 1999 The involvement of nitric oxide in corpus luteum regression in the rat: feedback mechanism between prostaglandin $\mathrm{F}(2 \alpha)$ and nitric oxide. Molecular Human Reproduction $\mathbf{5}$ 1011-1016. (doi:10.1093/molehr/5.11.1011)

Navarra P, Andreani CL, Lazzarin N, Pierro E, Mirtella A, Lanzone A \& Mancuso S 1996 Increased production and release of prostaglandin E, by human granulosa cells from polycystic ovaries. Prostaglandins $\mathbf{5 2}$ 187-197. (doi:10.1016/S0090-6980(96)00096-2)

Nelson-Degrave VL, Wickenheisser JK, Hendricks KL, Asano T, Fujishiro M, Legro RS, Kimball SR, Strauss JF \& McAllister JM 2005 Alterations in mitogen-activated protein kinase kinase and extracellular regulated kinase signaling in theca cells contribute to excessive androgen production in polycystic ovary syndrome. Molecular Endocrinology 19 379-390. (doi:10.1210/me.2004-0178)

Niccoli G, Apa R, Lanzone A, Liuzzo G, Spaziani C, Sagnella F, Cosentino N, Moro F, Martinez D, Morciano A et al. 2011 CD4+ CD28 null T lymphocytes are expanded in young women with polycystic ovary syndrome. Fertility and Sterility 95 2651-2654. (doi:10.1016/ j.fertnstert.2011.01.129)

Perkins ND 2007 Integrating cell-signalling pathways with NF-KB and IKK function. Nature Reviews Molecular Cell Biology 8 49-62. (doi:10.1038/ nrm2083)

Rask K, Zhu Y, Wang W, Hedin L \& Sundfeldt K 2006 Ovarian epithelial cancer: a role for PGE2-synthesis and signalling in malignant transformation and progression. Molecular Cancer 5 62-74. (doi:10. 1186/1476-4598-5-62)
Rekawiecki R, Nowik M \& Kotwica J 2005 Stimulatory effect of LH, PGE2 and progesterone on StAR protein, cytochrome P450 cholesterol side chain cleavage and $3 \beta$ hydroxysteroid dehydrogenase gene expression in bovine luteal cells. Prostaglandins \& Other Lipid Mediators 78 169-184. (doi:10.1016/j.prostaglandins.2005.06.009)

Rezvanfar M, Ahmadi A, Shojaei Saadi H, Baeeri M \& Abdollahi M 2011 Mechanistic links between oxidative/nitrosative stress and tumor necrosis factor $\alpha$ in letrozole-induced murine polycystic ovary: Biochemical and pathological evidences for beneficial effect of pioglitazone. Human \& Experimental Toxicology 31 887-897. (doi:10. 1177/0960327111426589)

Rezvanfar MA, Shojaei Saadi HA, Gooshe M, Abdolghaffari AH, Baeeri M \& Abdollahi M 2014 Ovarian aging-like phenotype in the hyperandrogenism-induced murine model of polycystic ovary. Oxidative Medicine and Cellular Longevity 2014 948951. (doi:10.1155/2014/ 948951)

Rosa-e-Silva A, Guimaraes MA, Padmanabhan V \& Lara HE 2003 Prepubertal administration of estradiol valerate disrupts cyclicity and leads to cystic ovarian morphology during adult life in the rat: role of sympathetic innervation. Endocrinology 144 4289-4297. (doi:10.1210/ en.2003-0146)

Rueda BR, Hendry IR, Tilly JL \& Hamernik DL 1999 Accumulation of caspase-3 messenger ribonucleic acid and induction of caspase activity in the ovine corpus luteum following prostaglandin F2a treatment in vivo. Biology of Reproduction 60 1087-1092. (doi:10. 1095/biolreprod60.5.1087)

Salvetti N, Canal AM, Gimeno EJ \& Ortega HH 2004 Polycystic ovarian syndrome: temporal characterization of the induction and reversion process in an experimental model. Brazilian Journal of Veterinary Research and Animal Science 41 389-395. (doi:10.1590/S141395962004000600006)

Salvetti NR, Acosta JC, Gimeno EJ, Muller LA, Mazzini RA, Taboada AF \& Ortega HH 2007 Estrogen receptors $\alpha$ and $\beta$ and progesterone receptors in normal bovine ovarian follicles and cystic ovarian disease. Veterinary Pathology 44 373-378. (doi:10.1354/vp.44-3-373)

Sheng H, Shao J, Morrow JD, Beauchamp RD \& DuBois RN 1998 Modulation of apoptosis and $\mathrm{Bcl}-2$ expression by prostaglandin E2 inhuman colon cancer cells. Cancer Research 58 362-366.

Shiina H, Matsumoto T, Sato T, Igarishi K, Miyamoto J, Takemasa S, Sakari M, Takada I, Nakamura T \& Metzger D 2006 Premature ovarian failure in androgen receptor-deficient mice. PNAS 103 224-229. (doi:10. 1073/pnas.0506736102)

Silvia WJ, Alter TB, Nugent AM \& Naranja da Fonseca LF 2002 Ovarian follicular cysts in dairy cows: an abnormality in folliculogenesis. Domestic Animal Endocrinology 23 167-177. (doi:10.1016/S0739-7240 (02)00154-6)

Sirotkin AV 2011 Cytokines: signalling molecules controlling ovarian functions. International Journal of Biochemistry \& Cell Biology 43 857-861. (doi:10.1016/j.biocel.2011.03.001)

Skarzynski DJ, Jaroszewski JJ \& Okuda K 2005 Role of tumor necrosis factor- $\alpha$ and nitric oxide in luteolysis in cattle. Domestic Animal Endocrinology 29 340-346. (doi:10.1016/j.domaniend.2005.02.005)

Snyder GD, Holmes RW, Bates JN \& Van Voorhis BJ 1996 Nitric oxide inhibits aromatase activity: mechanisms of action. Journal of Steroid Biochemistry and Molecular Biology 58 63-69. (doi:10.1016/09600760(96)00008-8)

Stener-Victorin E, Ploj K, Larsson BM \& Holmäng A 2005 Rats with steroid-induced polycystic ovaries develop hypertension and increased sympathetic nervous system activity. Reproductive Biology and Endocrinology 3 44-54. (doi:10.1186/1477-7827-3-44)

Takaya R, Fukaya T, Sasano H, Suzuki T, Tamura M \& Yajima A 1997 Macrophages in normal cycling human ovaries; immunohistochemical localization and characterization. Human reproduction 12 1508-1512. (doi:10.1093/humrep/12.7.1508)

Tamura K, Kawaguchi T, Hara T, Takatoshi S, Tohei A, Miyajima A, Seishi T \& Kogo H 2000 Interleukin-6 decreases estrogen production and messenger ribonucleic acid expression encoding aromatase during in vitro cytodifferentiation of rat granulosa cell. Molecular and Cellular Endocrinology 170 103-111. (doi:10.1016/S0303-7207(00)00334-8)

Taub DD 2008 Neuroendocrine interactions in the immune system. Cellular Immunology 252 1-6. (doi:10.1016/j.cellimm.2008.05.006) 
Thathapudi S, Kodati V, Erukkambattu J, Katragada A, Addepally U \& Hasan Q 2014 Tumor necrosis factor- $\alpha$ and polycystic ovarian syndrome: a clinical, biochemical, and molecular genetic study. Genetic Testing and Molecular Biomarkers 18 605-609. (doi:10.1089/gtmb. 2014.0151)

Tilly JL 2001 Commuting the death sentence: how oocytes strive to survive. Nature Review. Molecular and Cellular Biology 2 838-848. (doi:10. 1038/35099086)

Turner EC, Hughes J, Wilson H, Clay M, Mylonas KJ, Kipari T, Duncan WC \& Fraser HM 2011 Conditional ablation of macrophages disrupts ovarian vasculature. Reproduction 141 821-831. (doi:10.1530/REP-100327)

Tyndall V, Broyde M, Sharpe R, Welsh M, Drake AJ \& McNeilly AS 2012 Effect of androgen treatment during foetal and/or neonatal life on ovarian function in prepubertal and adult rats. Reproduction 143 21-33. (doi:10.1530/REP-11-0239)

Walters KA, Allan CM \& Handelsman DJ 2008 Androgen actions and the ovary. Biology of Reproduction 78 380-389. (doi:10.1095/biolreprod. 107.064089)
Wu R, Van der Hoek K, Ryan N, Norman R \& Robker R 2004 Macrophage contributions to ovarian function. Human Reproduction Update $\mathbf{1 0}$ 119-133. (doi:10.1093/humupd/dmh011)

Wu R, Fujii S, Ryan N, Van der Hoek K, Jasper M \& Sini I 2007 Ovarian leukocyte distribution and cytokine/chemokine mRNA expression in follicular fluid cells in women with polycystic ovary syndrome. Human reproduction 22 527-235. (doi:10.1093/humrep/del371)

Xiao C, Asselin E \& Tsang B 2002 Nuclear factor $\mathrm{\kappa B}$-mediated induction of flice-like inhibitory protein prevents tumor necrosis factor a-induced apoptosis in rat granulosa cells. Biology of Reproduction 67 436-441. (doi:10.1095/biolreprod67.2.436)

Received 9 May 2015

First decision 9 July 2015

Revised manuscript received 6 August 2015

Accepted 11 August 2015 